\title{
IMPLEMENTASI MODEL PEMBELAJARAN TERPADU DI SDI DARUSH SHOLIHIN KECAMATAN TANJUNGANOM KABUPATEN NGANJUK
}

\author{
Anwar \\ kanganwarsukses12@gmail.com \\ Sekolah Menengah Pertama Negeri (SMPN 3) Tanjunganom Nganjuk
}

\begin{abstract}
Abstrak.
Peneliti ini dibingkai dalam topik besar program implementasi model pembelajaran terpadu yang difokuskan agar dapat meningkatkan keefektifan peserta didik di SDI Darush Sholihin Nganjuk. Permasalahan yang diajukan dalam penelitian ini meliputi pertanyaan: 1). Bagaimanakah implementasi model pembelajaran terpadu di SDI Darush Sholihin Nganjuk. 2). Bagaimana implementasi model pembelajaran terpadu dapat meningkatkan keefektifan pembelajaran di SDI Darush Sholihin Nganjuk. Jenis pendekatan penelitian ini menggunakan Penelitian kualitatif dengan jenis studi kasus. Metode pengumpulan data dalam penelitian ini dilakukan dengan menggunakan tiga metode yaitu; Pengamatan terlibat (participant observation), Wawan cara mendalam (indepth interview) dan Dokumentasi. Data yang terkumpul setelah data dikumpulkan, lalu pengkodean kemudian diolah dan disajikan serta dibahas lalu dikumpulkan. Penelitian ini berhasil memperoleh temuan sesuai pertanyaan permasalahan yang pada garis besarnya dapat disimpulkan sebagai berikut:1) Pembelajaran terpadu di SDI Darush Sholihin menggunakan beberapa macam model yang digunakan berdasarkan pola pengintegrasian materi atau tema. Berdasarkan pola tersebut, terdapat sepuluh model pembelajaran terpadu yang dipakai SDI Darush Sholihin yaitu: (1) terpisah ( fragmented ), (2) terhubung (connected), (3) tersarang (nested), (4) terurut (sequenced), (5) terbagi (shared), (6) terjaring (webbed), (7) terikat (threaded), (8) terpadu (integrated), (9) terbenam (immersed), (10) jaringan (networked), Adapun bentuk atau model pembelajaran terpadu yang dirancang di SDI Darush Sholihin adalah bentuk tematik (terjala/webbed) untuk kelas bawah (1-3). 2) Keefektifan pembelajaran terpadu tercermin dari bermaknanya pembelajaran. Pembelajaran yang bermakna menghasilkan siswa yang aktif dalam proses belajar mengajar yang menyenangkan, sehingga terjadi komunikasi dua arah guru dan murid. Pembelajaran yang menyenangkan jika guru kreatif dan terdapat variasi cara belajar sehingga menghasilkan prestasi belajar yang baik
\end{abstract}

\section{Kata Kunci : Model Pembelajatan Terpadu, SDI Darush Sholihin Nganjuk}

\section{Pendahuluan}

Diselenggarakan arah pendidikan bukan sekedar agar siswa paham materi pembelajaran, namun lebih pada aktualisasi diri, adapun dengan menggunakan ilmu tersebut untuk kehidupan bermasyarakat dan pertanggungjawaban sebagai hamba Tuhan hal ini sesuai dengan pernyataan UNESCO. Commission on Education for Twenty-First Century menyampaikan bahwa UNESCO telah merekomendasikan empat pilar pendidikan (the four pillars of education) untuk memasuki era global.
The four pillars of education (empat pilar pendidikan) meliputi; "1) Learning to know, yang berarti belajar untuk mendapatkan pengetahuan dan melakukan pembelajaran selanjutnya. 2) Learning to do, yaitu belajar untuk memperoleh kemampuan dasar yang berhubungan dengan situasi dan tim kerja yang berbedabeda. 3) Learning to live together, yaitu belajar agar mampu mengapresiasikan dan mengamalkan kondisi saling ketergantungan, keanekaragaman, saling memahami dan perdamaian inter dan antar bangsa. 4) Learning to be, yaitu 
belajar untuk mengaktualisasikan diri sebagai individu dengan kepribadiannya yang memiliki tanggung jawab pribadi, termasuk belajar untuk menyadari dan mewujudkan diri sendiri sebagai warga negara dan hamba Tuhan dengan segala konsekuensi dan tanggung jawab". ${ }^{1}$

Untuk mempersiapkan peserta didik dengan seperangkat pengetahuan dan keterampilan agar bisa bekerja memenuhi kebutuhan dunia ekonomi, juga bermanfaat bagi diri dan orang lain, sesama, dan masyarakatnya hal ini merupakan tujuan pendidikan. ${ }^{2}$

Tujuan pendidikan dapat tercapai melalui pendidikan dan pengajaran yang sistematis seperti yang tercantum dalam Standar Pendidikan Nasional Pendidikan. Menurut Pasal 3 Undang-Undang Republik Indonesia Nomor 20 Tahun 2003 tentang Sistem Pendidikan Nasional fungsi dan tujuan.

Pendidikan Nasional berfungsi mengembangkan kemampuan dan membentuk watak serta peradaban bangsa,yang bermartabat dalam rangka mencerdaskan kehidupan bangsa, bertujuan untuk berkembangnya potensi peserta didik agar menjadi manusia yang beriman dan bertaqwa kepada Tuhan yang Maha Esa,berakhlak mulia,sehat, berilmu, cakap,kreatif,mandiri, dan menjadi warga negara yang demokratis serta bertanggung jawab. ${ }^{3}$

Usaha sadar dan terencana yang dilakukan pendidik untuk memanusiakan manusia melalui usaha pembentukaan kepribadian unggul dengan menitik beratkan pada proses pematangan kualitas logika, hati, akhlak, dan keimanan, sehingga usaha pengajaran yang dilakukan pendidik menghasilkan lulusan yang kreatif, dan dapat diterima di masyarakat dapat diartikan sebagai pendidikan

1 Abdul Majid. (2012). Belajar dan Pembelajaran Pendidikan Agama Islam. Bandung : Rosda.hal 2.

2 Zamroni. 2013. Pendidikan Populis Berbasis Budaya. Pidato Dies Natalis ke-63 Tahun 2013 FIP UNY.hal 13-14

3 Mulyasana, Dedi, (2012), Bermutu Pendidikan dan Berdaya Saing. Bandung: PT remaja rosdakarya. Hal 17. sederhana. Peran guru sangat penting agar tujuan pengajaran dapat terlaksana dengan baik, guru harus mampu memilih model pembelajaran yang tepat sesuai dengan model-model materi pelajaran yang akan disampaikan.

Pembelajaran terpadu diawali pada tahun 1991 dan merupakan suatu model pembelajaran yang baru di Amerika Serikat. Hal ini ditandai dengan ditulisnya buku Integrated Learning: Planned Curriculum Units Stage 3 karya Gillian Collins dan Hazel Dixon serta The Mindful School: How to Integrate the Curricula oleh Robin Fogarty. Adapun di Indonesia pada tahun 1993 merumuskan pembelajaran terpadu melalui Departemen Pendidikan Nasional sehingga lahirlah buku "Pembelajaran Terpadu" untuk Pendidikan Guru Sekolah Dasar (PGSD) yang ditulis oleh Tisno Hadi Subroto dan Ida Siti Herawati pada tahun 1998. Pembelajaran terpadu sangat berkembang untuk tingkat selanjutnya.

Hal ini dikarenakan model pembelajaran terpadu sangat berkembang dan belum adanya kejelasan model kurikulum terpadu dari Pusat Kurikulum, selama ini sebatas diberlakukannya pembelajaran terpadu bentuk tematik di kelas bawah SD. Adapun Model dan implementasi pembelajaran terpadu masih banyak terjadi perbedaan antara yang ada di buku acuan, dan dari Departemen Pendidikan Nasional, Pusat Kurikulum, juga sekolah yang menggunakannya.

Fogarty sudah merincikan bahwa pembelajaran terpadu menjadi sepuluh (10) tingkatan model beserta detail kurikulumnya. Ada perbedaan Model pembelajaran terpadu dalam keterangan buku acuan Collins \& Dixon serta Fogarty, walaupun secara garis besarnya sama. Collin \& Dixon hanya menggambarkan pembelajaran terpadu dan kurikulumnya secara global. 4

Penggunaan pembelajaran terpadu belum sepenuhnya digunakan karena kesulitan pada rancangan kurikulumnya.

4 Mathews, Barbara dan Pauline Cleary. 2010 . The Integrated Curriculum in Use.New York: Ashton Scholastic.halm 2-3. 
Keumuman model Collins \& Dixon serta kekhususan model Fogarty diramu Departemen Pendidikan Nasional dalam bukunya, hanya saja modelnya menjadi tidak jelas dan hanya dibatasi menjadi tiga (3) model saja. Pada tataran aplikasi, DEPDIKNAS dengan melalui Pusat Kurikulum menetapkan bahwa pembelajaran pada tingkatan kelas bawah (1-3) dilaksanakan melalui pendekatan tematik sedangkan pada tingkatan kelas atas (4-6) dilaksanakan melalui pendekatan mata pelajaran. ${ }^{5}$

Oleh karena itu Pembelajaran terpadu sebagai suatu model dapat dikatakan dengan pendekatan suatu belajar mengajar yang melibatkan beberapa bidang studi yang memberikan pengalaman bermakna kepada anak didik. ${ }^{6}$ Pembelajaran terpadu juga terjadi ketika suatu kejadian atau eksplorasi dari suatu topic merupakan tenaga pendorong dalam kurikulum. Pembelajaran terpadu berdasarkan pada pendekatan inkuiri dengan pembelajar dilibatkan pada perencanaan, eksplorasi dan diskusi ide. Pembelajaran terpadu sebagai suatu proses mempunyai beberapa karakteristik atau ciri-ciri, yaitu: holistik, bermakna, otentik, dan aktif . ${ }^{7}$

Dijelaskan juga oleh Tisno Hadi Subroto dan Ida Siti Herawati bahwa Tahap perkembangan kognifif anak SD yang masih dalam tahap operasional konkret diperlukannya pembelajaran terpadu di Sekolah Dasar (SD) karena kemampuan berpikir dan kebutuhan psikologis yang khusus bagi pebelajar di SD. Agar semua pembelajaran di SD menjadi lebih efektif. 8

5 Pusat Kurikulum. 2010. Model Kurikulum Inovatif Pendidikan Dasar. Jakarta:Badan Penelitian Dan Pengembangan Pendidikan Departemen Pendidikan Nasional. halm 11.

6 Trianto. 2011. Model Pembelajaran Terpadu dalam Teori dan Praktek. Jakarta: Prestasi Pustaka Publisher. Halm 7.

7 Departemen Pendidikan Nasional. 2010. Pembelajaran Terpadu D-II PGSD dan S-2 Pendidikan Dasar. Jakarta: Depdiknas. Halm 3.

8 Tisno Hadi Subroto dan Ida Siti Herawati. 2011. Pembelajaran Terpadu. Jakarta: Pusat Penerbitan Universitas Terbuka.halm 1.10-1.12, 3.2
Terkait dengan pembelajaran terpadu sekolah membentuk kurikulum yang dipakai. Sekolah yang menggunakan sistem pembelajaran terpadu belum tentu memakai kurikulum terpadu juga. Pusat Kurikulum sendiri belum mempunyai model yang jelas tentang kurikulum terpadu yang selayaknya ada sebelum dilaksanakannya pembelajaran terpadu. Walaupun ada perbedaan definisi pembelajaran terpadu dan kurikulum terpadu, implementasi pembelajaran terpadu tentu diawali dengan suatu bentuk kurikulum.

Pembelajaran terpadu merujuk pada pendekatan dalam belajar meskipun kurikulum belum terpadu, Pada tataran aplikasi, pengertian pembelajaran terpadu dan kurikulum terpadu saling melengkapi dan dapat dipertukarkan seperti kurikulum pendidikan dasar sekarang. ${ }^{9}$ Sekolah yang sudah mulai menggunakan model pembelajaran terpadu pada aplikasinya masih menggunakan Kurikulum Tingkat Satuan Pendidikan (KTSP), terkecuali jika sekolah tersebut langsung mengacu pada buku Collins \& Dixon atau Fogarty.

Kurikulum terpadu menunjukkan pendekatan antar cabang ilmu pengetahuan (interdisipliner). ${ }^{10}$ Kurikulum terpadu berpusat pada siswa, topik merupakan perpaduan lintas kurikulum, kecakapan menyatu dalam suatu pembelajaran, metode dan lingkungan kelas yang fleksibel, bebas menemukan dan menyelidiki pertanyaan terbuka. ${ }^{11}$

Dalam kurun waktu sepuluh tahun terakhir, dunia pendidikan dasar memiliki fenomena unik dengan banyak berdirinya Sekolah Dasar Islam (SDI). Perkembangan pembelajaran terpadu telah diikuti dengan bermunculan model sekolah inovasi dengan mengusung slogan Islam Terpadu. Secara umum, fenomena ini berangkat dari

9 Semiawan, Conny R. 2011. Belajar dan Pembelajaran Prasekolah dan Sekolah Dasar. Jakarta: Indeks.halm 77.

10 Fogarty, Robin. 2012. The Mindful School: How to Integrate the Curricula. Palatine: Skylight Publishing Inc.halm 74.

11 Mathews, Barbara dan Pauline Cleary. 2010. The Integrated Curriculum in Use. New York: Ashton Scholastic.halm 1-3. 
kesadaran masyarakat yang melihat bahwa fungsi pendidikan di sekolah dasar adalah pondasi dari pendidikan selanjutnya. Pembentukan kecerdasan tidak hanya dari nilai umum tapi juga dengan nilai agama, khususnya agama Islam. Masa pendidikan dasar adalah masa keemasan pendidikan moral. Hal ini akan menentukan bagaimana anak didik selanjutnya berkembang. Kemerosotan moral masyarakat kebanyakan disebabkan pendidikan nilai agama pada anak-anak usia sekolah dasar diabaikan.

Untuk melaksanakan pembelajaran mengajar seorang guru sangat memerlukan model dalam proses belajar mengajar disekolah sebagai penunjang untuk mencapai tujuan pembelajaran yang diharapkan. menurut Joyce dan Weill mengatakan bahwa "Model pengajaran sebagai rencana atau pola yang dapat digunakan untuk membentuk kurikulum, mendesain materi-materi instruksional, dan memandu proses pengajaran di ruang kelas atau di setting yang berbeda".12 Model pembelajaran dapat diartikan sebagai cara, contoh maupun pola yang mempunyai tujuan menyajikan pesan kepada peserta didik agar dapat dipahami, dengan memperhatikan kemampuan peserta didik, materi dan kelas yang digunakan sebagai penerapan model pembelajaran tersebut.

Oleh karena itu, berdirinya SDI di berbagai tempat, merupakan implementasi terhadap keperluan memadukan pembinaan moral (dalam hal ini Aqidah dan Akhlak dalam agama Islam) dan keperluan penyampaian materi umum sebagaimana yang ada di Sekolah Dasar (SD). Format pelaksanaan kegiatan belajar mengajar dilaksanakan dari pagi hingga sore hari dengan rangkaian kegiatan yang dianggap mampu mengakomodasi dua keperluan utama tersebut. Hal tersebut lebih populer disebut full day school.

Secara pararel, adanya asumsi yang terbangun di masyarakat tentang jaminan terjaganya moral melalui pembinaan

12 Huda, M. (2013). Model-model Pengajaran dan Pembelajaran. Yogyakarta: Pustaka Pelajar.hal 73. akhlak dan keberhasilan materi umum melalui serangkaian inovasi sistem pembelajaran yang biasanya ditawarkan oleh sekolah, ternyata cukup kuat. Hal itu terbukti kebanyakan konsumen SDI adalah golongan ekonomi menengah ke atas yang dapat pula memberikan indikasi adanya kepercayaan utuh sebuah tingkatan masyarakat yang memiliki latar belakang intelektualitas tinggi, di samping memang biaya sekolah di SDI jauh lebih tinggi dibandingkan SD umumnya walaupun asumsi itu belum terukur.

Sistem pembelajaran terpadu di SDI pada umumnya belum menunjukkan kemajuan dari segi kualitas. peningkatan keberadaan SDI di Indonesia masih sebatas pada kuantitas. ${ }^{13}$ Hal ini nampak dari masih adanya dikotomisasi pendidikan ilmu agama dengan ilmu umum. Ilmu agama yang diajarkan pada SDI hanya sebagai tambahan yang mendampingi pengajaran ilmu umum. Dengan kata lain, pendidikan ilmu agama itu sendiri belum terpadu dengan ilmu umum. Apabila sistem pembelajaran terpadu yang masih terdapat pemisahan antara ilmu agama dan ilmu umum, maka sistem pembelajaran yang terbentuk adalah sistem pembelajaran biasa. Pengembangan sistem pembelajaran dilakukan guna menjembatani antara potensi yang telah dimiliki anak didik dengan ekspektasi hasil dari sistem pembelajaran.

Hal yang menarik Sekolah Dasar Islam selama ini dipayungi oleh Departemen Pendidikan Nasional bukan oleh Departemen Agama. karena kecenderungan umum jika sekolah agama akan bergabung ke Departemen Agama. Penggunaan slogan Islam terpadu sendiri tentu mempunyai model yang melatar belakangi. Model tersebut bisa sama dengan model yang ada pada buku acuan, Departemen Pendidikan Nasional dan Pusat Kurikulum serta bisa pula hal yang berbeda. Implementasi model pembelajaran terpadu di SDI bisa saja berbeda dengan 3 model yang baru ada di

13 Muhammad Syaerozi Dimyathi. 2017. http://www.republika.co.id /cetak_detail.asp? id=82163\&kat_id=3. Diakses tanggal 25 Maret 2017. 
Indonesia. Hal ini dikarenakan masih ada 7 dari 10 model menurut Fogarty yang masih mungkin untuk dilaksanakan atau bahkan SDI mempunyai model yang berbeda. ${ }^{14}$ Inilah yang hendak digali peneliti, kesinambungan model sistem pembelajaran terpadu dan implementasinya menurut buku acuan, Departemen Pendidikan Nasional, Pusat Kurikulum, dan SDI Darush Sholihin.

Sekolah Dasar Islam (SDI) Darush Sholihin Nganjuk berdiri pada tahun ajaran 2002/ 2003. Sekolah ini merupakan Sekolah Dasar yang menerapkan kegiatan belajar mengajar dari pagi sampai sore (full day school), yang memadukan antara kurikulum pendidikan Pondok Pesantren dengan kurikulum pendidikan konvensional. Sekolah Dasar Islam (SDI) Darush Sholihin Nganjuk merupakan salah satu dari angggota Forum Komunikasi Lembaga Pendidikan Islam (FKLPI). Forum tersebut mewadahi sekolah-sekolah Islam yang berada dalam naungan Departemen Pendidikan Nasional.

Sekolah Dasar Islam (SDI) Darush Sholihin Nganjuk telah melaksanakan sistem pembelajaran terpadu mulai tahun ajaran 2004/ 2005 dengan Kurikulum Berbasis Kompetensi (KBK). Sejak tahun ajaran 2007/ 2008 SDI Darush Sholihin Nganjuk menggunakan KTSP. Sekolah Dasar Islam (SDI) Darush Sholihin Nganjuk berada di bawah pantauan Departemen Pendidikan Nasional.

Kurikulum pembelajaran yang dipakai SDI Darush Sholihin Nganjuk berdasarkan pada tiga macam kurikulum, yaitu kurikulum muatan umum, kurikulum program khusus dan kurikulum ekstra kurikuler. Kurikulum muatan umum terdiri dari kurikulum DIKNAS dan DEPAG. Kurikulum program khusus terdiri dari multimedia, qiro'atul Qur'an, sempoa, tahfidzul Qur'an, dan bahasa Arab. Kurikulum Ekstra Kurikuler terdiri dari kepanduan, life skill, bela diri, renang, komputer dan tata boga.

14 Fogarty, Robin. 2011. The Mindful School: How to Integrate the Curricula. Palatine: Skylight Publishing Inc. halm xi-xv
Keunggulan SDI Darush Sholihin Nganjuk yaitu pada program tahfidzul $\mathrm{Al}$ Qur'an. Hal ini dibuktikan pada perlombaan Tahfidzul Qur'an tingkat Nganjuk 2007, SDI Darush Sholihin Nganjuk menjadi juara I dan II. Pada tahun 2008, SDI Darush Sholihin Nganjuk menjadi juara I, II, dan III yang diadakan oleh Syifa Organizer. Indikasi keterpaduan pembelajaran sistem Islam yaitu penekanan dasar agama Islam (Al Qur'an dan Hadist) pada pembelajaran. Kondisi tersebut akan memperkuat tonggak pendidikan secara umum dan meningkatkan prestasi belajar siswa, tidak hanya peningkatan pengetahuan umum.

Berdasarkan uraian diatas, maka peneliti tertarik untuk mengadakan penelitian yang judul "implementasi model pembelajaran terpadu di SDI", penelitian ini dianggap penting karena dengan adanya penerapan model pembelajaran terpadu oleh peneliti diharapkan dapat meningkatkan hasil belajar peserta didik khususnya di Darush Sholihin Nganjuk.

Berdasarkan Konteks tersebut, Peneliti dapat memfokuskan pada penelitian ini adalah, implementasi model pembelajaran terpadu di SDI Darush Sholihin Nganjuk, dan efektifitas pembelajaran terpadu di SDI Darush Sholihin Nganjuk.

\section{Kajian Pustaka \\ Pembelajaran Terpadu}

Pembelajaran terpadu sebagai suatu konsep dapat dikatakan sebagai suatu pendekatan belajar mengajar yang melibatkan beberapa bidang studi untuk memberikan pengalaman bermakna kepada anak didik. Pembelajaran terpadu merupakan suatu sistem pembelajaran yang memungkinkan siswa, baik secara individual maupun kelompok, aktif mencari, menggali dan menemukan konsep serta prinsip keilmuan secara holistik, bermakna, dan otentik ${ }^{15}$.

Pengajaran terpadu pada dasarnya dimaksudkan sebagai kegiatan mengajar

15 Trianto. 2011. Model Pembelajaran Terpadu dalam Teori dan Praktek. Jakarta: Prestasi Pustaka Publisher. Halm 6-9 
dengan memadukan materi beberapa mata pelajaran dalam satu tema. Dengan demikian, pelaksanaan kegiatan belajar mengajar dengan cara ini dapat dilakukan dengan mengajarkan beberapa materi pelajaran disajikan tiap pertemuan. ${ }^{16}$

Secara umum prinsip-prinsip pembelajaran terpadu dapat diklasifikasikan menjadi: (1) prinsip penggalian tema; (2) prinsip pengelolaan pembelajaran; (3) prinsip evaluasi; dan (4) prinsip reaksi.

\section{Model-Model Pembelajaran Terpadu}

Pembelajaran terpadu dibedakan berdasarkan pola pengintegrasian materi atau tema. Berdasarkan pola tersebut, terdapat sepuluh model pembelajaran terpadu. ${ }^{17}$ yaitu: (1) terpisah ( fragmented ), (2) terhubung (connected), (3) tersarang (nested), (4) terurut (sequenced), (5) terbagi (shared), (6) terjaring (webbed), (7) terikat (threaded), (8) terpadu (integrated), (9) terbenam (immersed), (10) jaringan (networked).

Secara umum dari kesepuluh model pembelajaran terpadu tersebut dapat dikelompokkan menjadi 3 klasifikasi pengintegrasian kurikulum, yakni: pertama, pengintegrasian di dalam satu disiplin ilmu; kedua, pengintegrasian beberapa disiplin ilmu; ketiga, pengintegrasian di dalam dan beberapa disiplin ilmu.

\section{Fragmented (terpisah)}

Kurikulum tradisional yang menetapkan untuk memisahkan dan membedakan mata pelajaran. Dalam standar kurikulum, areal pokok persoalan ini dipisahkan, jadi tidak ada usaha untuk menghubungkan atau menggabungkannya. Masing-masing ilmu terlihat murni dan apa adanya.

\section{Connected (terhubung)}

Model kurikulum berfokus pada pembuatan hubungan yang jelas tiap pelajaran, menghubungkan satu topik ke topik berikutnya, menghubungkan satu

16 Ibid,..halm 7

17 Fogarty, Robin. (2011). The Mindful School: How to Integrate the Curricula. Palatine: Skylight Publishing Inc. Halm xv. konsep dengan konsep yang lainnya, menghubungkan satu keterampilan ke keterampilan yang lain, menghubungkan pekerjaan satu hari ke hari berikutnya, atau bahkan ide satu semester ke semester berikutnya. Kunci model ini adalah usaha untuk menghubungkan kurikulum dengan disiplin ilmu dari asumsi bahwa siswa akan mengerti hubungan secara otomatis.

\section{Nested (tersarang)}

Model ini dari pembelajaran terpadu adalah rancangan yang digunakan oleh para guru dalam kegiatan pembelajaran. Namun, di dalam suatu pembelajaran yang menggunakan pendekatan nested, diperlukan sebuah perencanaan yang sungguh-sungguh untuk menyusun target ganda dari pembelajaran siswa. Bagaimanapun juga, keterpaduan model nested ini memberikan keuntungan kombinasi alamiah sehingga tugas-tugas menjadi kelihatan lebih mudah.

4. Sequenced (terurut)

Sehubungan dengan terbatasnya hubungan antar disiplin ilmu yang berbeda, guru bisa menyusun kembali topik-topik pembelajaran. Jadi, mata pelajaran yang memiliki persamaan ide bisa bertepatan. Dua disiplin ilmu yang berkaitan bisa dapat diurutkan. Dengan mengurutkan topik-topik yang diajarkan aktivitas dari masing-masing bisa mendorong topik yang satunya. Dengan kata lain, satu topik mendukung topik yang lain demikian pula sebaliknya.

5. Shared (terbagi)

Perluasan disiplin menciptakan payung yang mencakup kurikulum: ilmu pasti dan ilmu pengetahuan dipasangkan sebagai ilmu, sastra dan sejarah dipasangkan di bawah label kemanusiaan: seni, musik, tari, dan drama dipandang sebagai seni-seni indah, teknologi komputer, industri, dan seni rumah dipasangkan sebagai seni praktik. Dalam beberapa disiplin komplementer, perencanaan dan atau guru menciptakan fokus pada konsep bersama, keahlian dan sikap.

6. Webbed (terjaring)

Kurikulum webbed menggambarkan pendekatan tematik untuk meng- 
integrasikan materi pokok. Sebuah tim lintas departemen membuat sebuah keputusan yang menggunakan tema seperti sebuah lapisan untuk subjek yang berbeda. Dalam penerapan model webbed yang lebih rumit, bagian yang berbelitbelit dalam pelajaran dapat dibangun menjadi terintegrasi dalam semua area yang relevan.

\section{Threaded (terikat)}

Model threaded dari kurikulum terpadu ini memfokuskan pada metakurikulum yang menggantikan atau memotong inti dari beberapa dan semua muatan mata pelajaran. Strategi-strategi pencarian konsensus digunakan untuk menyelesaikan konflik-konflik dalam situasi yang membutuhkan penyelesaian masalah. Keterampilan-keterampilan ini intinya dirangkai melalui muatan kurikulum standar.

\section{Integrated (terpadu)}

Model kurikulum yang dipadukan menunjukkan pendekatan dari antar cabang ilmu pengetahuan hampir sama dengan model shared. Model integrated menekankan pada empat disiplin mayor dengan menata prioritas kurikulum dan menemukan keterampilan, konsep, dan sikap dalam empat bagian. Seperti pada model shared, pemaduan adalah hasil dari penyaringan ide dari isi suatu materi pelajaran, bukan meletakkan ide pada subjek-subjek itu seperti yang ada dalam pendekatan tema webbed. Pemaduan muncul dari dalam variasi disiplin dan pasangan itu dibuat diantaranya sebagai komunitas yang baru muncul.

\section{Immersed (terbenam)}

Para lulusan, kandidat doktor dan guru besar melebur total dalam satu bidang studi. Mereka menyaring berbagai kurikulum pembelajaran melalui satu lensa mikroskopik. Individu ini memadukan semua data (dari berbagai bidang dan disiplin ilmu) dengan cara menyalurkan berbagai ide sesuai bidang minat masingmasing. Pada model kurikulum terpadu ini, pebelajar bisa berintegrasi secara internal dan intrinsik hanya dengan sedikit atau tanpa intervensi ekstrinsik.

\section{Networked (terjaring)}

Model networked pembelajaran terpadu adalah keberlanjutan sumber input eksternal yang selalu memberikan ide-ide baru, diperluas dan diperbaiki atau dengan masukan khusus. Jalinan kerja profesional siswa ini biasanya dilaksanakan pada aturan-aturan yang jelas dan kadang-kadang tidak begitu jelas. Dalam mencari informasi utama para siswa bergantung pada jalinan kerja ini sebagai sumber informasi utama yang harus mereka saring melalui lensa keahlian dan minat mereka sendiri. Model networked tidak seperti model-model terdahulu, siswa langsung memadukan proses melalui seleksi dari jalinan-jalinan kerja yang diperlukan. Model ini berkembang dan tumbuh sepanjang perjalanan waktu seperti diperlukannya pengalihan siswa ke dalam situasi yang baru.

\section{Metode Penelitian}

Penelitian ini menggunakan pendekatan kualitatif, sementara penggalian datanya diimput dengan metode obervasi, interview, dan dokumentasi. Sedangkan analisis datanya menggunakan analisis kualitatif dengan tiga tahapan, yakni 1) reduksi data (data reduction), 2) penyajian data (data displays dan 3) penarikan kesimpulan/ verifikasi (conclusion drawing/veriffication). Komponen alur tersebut dijelaskan dengan tahapan-tahapan sebagai berikut:

Pertama, reduksi data, yang merupakan suatu bentuk analisis yang menajamkan, menggolongkan, mengarahkan, membuang yang tidak perlu dan mengorganisasi data sedemikian rupa sehingga diperoleh kesimpulan akhir dan diverifikasi. Reduksi data berlangsung terus menerus selama penelitian berlangsung bahkan sebelum data benarbenar terkumpul sudah mengantisipasi akan adanya reduksi data sudah tampak sewaktu memutuskan kerangka konseptual, wilayah penelitian, permasalahan penelitian, dan penentuan metode pengumpulan data. Selama pengumpulan data berlangsung sudah terjadi tahapan reduksi, selanjutnya 
(membuat ringkasan, mengkode, menelusuri tema, membuat gugus-gugus, menulis memo). Proses ini berlanjut sampai pasca pengumpulan data di lapangan, bahkan pada akhir pembuatan laporan sehingga tersusun lengkap.

Kedua, penyajian data, sebagaimana ditegaskan oleh Miles dan Huberman,18 bahwa penyajian data dimaksudkan untuk menemukan pola-pola yang bermakna serta memberikan kemungkinan adanya penarikan kesimpulan dan pengambilan tindakan. Penyajian data dalam penelitian ini juga dimaksudkan untuk menemukan suatu makna dari data-data yang telah diperoleh, kemudian disusun secara sistematis, dari bentuk informasi yang kompleks menjadi sederhana namun selektif.

Ketiga, Penarikan kesimpulan/ Verifikasi, Kegiatan analisis pada tahap ketiga adalah menarik kesimpulan dan verifikasi. Sejak pengumpulan data peneliti berusaha mencari makna atau arti dari simbol-simbol, mencatat, keteraturan pola, penjelasan-penjelasan, dan alur sebab akibat yang terjadi. Dari kegiatan ini dibuat simpulan-simpulan yang sifatnya masih terbuka, umum, kemudian menuju ke yang spesifik/rinci. Kesimpulan final diharapkan dapat diperoleh setelah pengumpulan data selesai

\section{Hasil Penelitian}

Kurikulum yang digunakan Proses pembelajaran pendidikan mengacu pada kurikulum Departemen Pendidikan Nasional Republik Indonesia dan diintegrasikan dengan muatan-muatan pendidikan islam, Kurikulum di SDI Darush Sholihin dibagi menjadi dua yaitu kurikulum inti dan kurikulum penunjang.

Tesis dengan judul "Implementasi Model Pembelajaran Terpadu di SDI Darush Sholihin kec. Tanjunganom kab. Nganjuk" mengedepankan pada penerapan model pembelajaran terpadu.

Model pembelajaran terpadu yang dipandang layak untuk dikembangkan dan

18Miles M. B \& Huberman A. Mikel, Qualitative Data Analisis, (Beverly Hills: SAGE Publication inc, 1992), 21-22. mudah dilaksanakan pada pendidikan formal (sekolah dasar) adalah the connected model (model terhubung), the webbed model (model jaring laba-laba), danthe integrated model (model integrasi). Selain itu, ada pula jenis model pembelajaran terpadu yang dapat dilaksanakan antara lain: (1) The nested model (model tersarang); (2) The fragmented model (model fragmen); (3) The sequenced model (model terurut); (4) The shared model (model terbagi); (5) The threaded model (model pasang benang); (6) The immersed model (model terbenam); dan (7) The networked model (model jaringan). Semua model tersebut di atas baik apabila digunakan sesuai dengan situasi dan kebutuhan serta disertai dengan keprofesionalan guru dalam mengembangkannya.

Model pembelajaran terpadu yang diterapkan di SDI Darush Sholihin untuk mencapai visi dan misi tersebut dibagi menjadi 2 (dua) bentuk. Bentuk pertama adalah STL (Subyek Times Lesson) yang merupakan pembelajaran permata pelajaran untuk penguasaan model dasar. Bentuk kedua adalah PBL (Proyek Based Learning) merupakan pembelajaran dengan menggabungkan beberapa mata pelajaran dalam satu waktu. Jadwal pelajaran di SDI Darush Sholihin tahun ajaran 2016/2017 disepakati untuk hari Senin dan Selasa diselenggarakan STL yang dikelola oleh guru persubyek pelajaran. Sedangkan hari Rabu, Kamis, dan Jumat diselenggarakan PBL yang dikelola dengan model team teaching.

Dengan adanya pemaduan itu, siswa akan memperoleh pengetahuan dan ketrampilan secara utuh sehingga pembelajaran menjadi bermakna bagi siswa. Memberikan makna bahwa pada pembelajaran terpadu siswa akan dapat memahami materi yang mereka pelajari melalui pengalaman langsung dan nyata yang menghubungkan antar model dalam intra mata pelajaran maupun antar mata pelajaran.

Fenomena diatas bertujuan untuk memadukan materi mata pelajaran Pendidikan agama dan kurikulum 
pendidikan umum agar pendidikan agama dengan pendidikan umum imbang dikehidupan peserta didik setiap hari, meskipun ada perbedaan yang nampak di sekolah dasar tapi ada letak kesamaan semuanya agar proses belajar mengajar peserta didik mendapat variasi belajar akhirnya peserta didik tidak membosankan dan anak didik memunculkan banyak kreasi, aktif dan efektif belajar.

\section{Kesimpulan}

Berdasarkan hasil penelitian melalui analisis wawancara, hasil pengamatan, dan dokumentasi yang telah dikemukakan pada bab IV ditarik kesimpulan sebagai berikut:

Pertama, Pembelajaran terpadu di SDI Darush Sholihin menggunakan beberapa macam model yang digunakan berdasarkan pola pengintegrasian materi atau tema. Berdasarkan pola tersebut, terdapat sepuluh model pembelajaran terpadu yang dipakai SDI Darush Sholihin yaitu: (1) terpisah ( fragmented ),(2) terhubung (connected), (3) tersarang (nested), (4) terurut (sequenced), (5)terbagi (shared), (6) terjaring (webbed), (7) terikat (threaded), terpadu(integrated), (9) terbenam (immersed), (10) jaringan (networked). Untuk digunakan Kurikulum Tingkat Satuan Pendidikan (KTSP). Dirancang jenis terjala (webbed) atau tematik untuk kelas bawah (1, 2, dan 3) dan jenis terkait untuk kelas atas $(4,5$, dan 6$)$. Mata pelajaran yang dipadukan adalah PPKN, bahasa Indonesia, Matematika, IPA, IPS, KTK, dan bahasa Jawa. Tim penyusun kurikulum yaitu unsur sekolah dan komite sekolah dibawah koordinasi Dinas Pendidikan Kota. Sistematika rancangan pembelajaran terpadu yaitu tim penyusun kurikulum berkumpul untuk menentukan tema pada tiap bidang studi atau antar bidang studi dan membuat perangkat pembelajaran untuk tiap mata pelajaran.

Kedua, Efektifitas pembelajaran terpadu yang ada di SDI Darush Sholihin tercermin dari bermaknanya pembelajaran. Pembelajaran yang bermakna menghasilkan siswa yang aktif dalam proses belajar mengajar yang menyenangkan, sehingga terjadi komunikasi dua arah guru dan murid. Pembelajaran yang menyenangkan jika guru kreatif dan terdapat variasi cara belajar sehingga menghasilkan prestasi belajar yang baik.

\section{Daftar Pustaka}

Dedi, M. (2012), Bermutu Pendidikan dan Berdaya Saing. PT remaja rosdakarya, Bandung.

Departemen Pendidikan Nasional. (2010) Pembelajaran Terpadu D-II PGSD

Dick, Walter, Lou Carey, \& James O. Carey. (2011) The Systematic Design of

$$
\begin{aligned}
& \text { Dimyathi, M. S. } \\
& \text { http://www.republika.co.id } \\
& \text { /cetak_detail.asp? id=82163\& } \\
& \text { katid=3.Diakses tanggal } 25 \text { Maret }
\end{aligned}
$$

Dimyati dan Mudjiono. (2012) Belajar dan Pembelajaran. PT Asdi Mahasatya, Jakarta.

Djamarah, S. B dan Zain, A. (2012). Strategi Belajar Mengajar. Rineka Cipta. Jakarta.

Emzir. (2012) Metodologi Penelitian Kualitatif Analisis Data, Raja Grafindo

Emzir. (2012), Metodologi Penelitian Kualitatif Analisis Data,Raja Grafindo Persada, Jakarta.

Fogarty, Robin. (2011) The Mindful School: How to Integrate the Curricula. Skylight Publishing Inc, Palatine.

Frazee, B. M. \& R. A. Rudmitski. (2012) Integrating Teaching Methods. Delmar Publishers, Washington.

Gillian, C and Dixon, H. (2011) Integrated Learning: Planned Curriculum Units

Gunawan, I. (2015) Metode Penelitian Kualitatif Teori Dan Praktik, Bumi

Gunawan,I. (2015), Metode Penelitian Kualitatif Teori Dan Praktik, Bumi Aksara, Jakarta.

Hamalik, O. (2010) Kurikulum dan Pembelajaran. Bumi Aksara, Jakarta.

Hartono. (2011) Pendidikan Integratif. Stain Press, Purwokerto. 
Huda, M. (2013) Model-model Pengajaran dan Pembelajaran. Pustaka Pelajar, Yogyakarta. Instruction (5th ed). Addison-Wesley Educational Publishers Inc, New Jakarta.

Kozma, Robert B., Laowren W. Belle, and George W.Williams. (2012) Instructional Techniques in Higher Education. Educational Technology Publ, Englewood Cliffs.

Majid, A. (2012) Belajar dan Pembelajaran Pendidikan Agama Islam. Rosda.

Mardalis. (2014), Metode Penelitian Suatu Pendekatan Proposal, Bumi Aksara, Jakarta.

Mathews, Barbara dan Pauline Cleary. (2011) The Integrated Curriculum in Use. Ashton Scholastic, New York.

Mayer, Richard E. (2012) "Designing Instruction for Constructivist Learning"dalam Reigeluth, Charles M. Instructional Design Theories and Model Volume II: A New Paradigm of Instructional Theory. Lawrence Erlbaum Associates, Publ. Mahwah

Morisson, Gary R., Steven M. Ross, and Jerrold E. Kemp. (2010) DesigningEffective Instruction (3th ed). John Wiley \& Sons, Inc, New York Persada, Jakarta.

Prabowo. (2011) Pembelajaran Fisika dengan Pendekatan Terpadu dalam Menghadapi Perkembangan IPTEK Milenium III. Makalah. Disampaikan pada Seminar dan Lokakarya Jurusan Fisika FMIPA Unesa Bekerja sama dengan Himpunan Fisika Indonesia (HFI) dengan Tema Optimalisasi Peranan Fisika Menghadapi Perkembangan IPTEK Milenium IIII pada tanggal 10 Pebruari 2011.

Pusat Kurikulum. (2010) Model Kurikulum Inovatif Pendidikan Dasar. Badan Penelitian Dan Pengembangan Pendidikan Departemen Pendidikan Nasional, Jakarta.

Putra, N. (2013), Metode Penelitian Kualitatif Manajemen, Raja Grafindo Persada, Jakarta.

Reigeluth, Charles M. (2011) "What is Instructional-Design Theory and How Is It Changing?" dalam
Reigeluth, Charles M. Instructional Design Theories and Model Volume II: A New Paradigm of Instructional Theory. (p.5-29) Lawrence Erlbaum Associates, Publ. Mahwah. S-2 Pendidikan Dasar. Depdiknas, Jakarta.

Semiawan, Conny, R. 2011. Belajar dan Pembelajaran Prasekolah dan Sekolah Dasar. Indeks. Jakarta.

Soetarno Joyoatmojo. 2013. Pembelajaran Efektif: Upaya Peningkatan Kualitas Lulusan Menuju Penyediaan Sumber Daya Insani yang Unggul. Sebelas Maret University Press, Surakarta. Stage 3. Bookshelf Publishing, Gosford.

Subroto, T. H dan Herawati, I. S. (2011) Pembelajaran Terpadu. Pusat Penerbitan Universitas Terbuka, Jakarta.

Sulasmi, S. (20011) Implementasi Model Pembelajaran Terpadu pada Sekolah Inklusi (Tesis). Program Pascasarjana UNS, Surakarta.

Suparman, A. (2011). Desain Instruksional, PAU-PPAI, Universitas Terbuka,

Suprihatiningrum, Jamil. (2013). Strategi Pembelajaran. Ar-Ruzz Media, Maguwoharjo.

Trianto, (2010). Model Pembelajaran Terpadu: Konsep, Strategi, dan Implementasinya Dalam Kurikulum Tingkat Satuan Pendidikan (KTSP). Bumi Aksara, Jakarta.

Trianto. (2011) Model Pembelajaran Terpadu dalam Teori dan Praktek. Prestasi Pustaka Publisher, Jakarta.

Walter, W and Robert, A. (2012). Planning Effective Instruction. Allyn and

Winataputra, U. S. (2011). "Model-Model Pembelajaran" dalam Toeti Soekamto dan Udin Saripudin Winataputra. Teori Belajar dan Model-Model Pembelajaran.PAUPPAI, UT, Jakarta.

Zamroni. (2013) Pendidikan Populis Berbasis Budaya. Pidato Dies Natalis ke-63 Tahun 2013 FIP UNY. 